\title{
Best constant in Hyers-Ulam stability of some functional equations
}

\section{DORIAN POPA and IOAN RAŞA}

\section{ABSTRACT.}

We obtain the infimum of Hyers-Ulam constants for Cauchy, Jensen and Quadratic functional equations. Moreover, in each case the infimum is itself a Hyers-Ulam constant.

\section{REFERENCES}

[1] Brillouët-Beluot, N., Brzdęk, J. and Ciepliński, K., On some recent developments in Ulam's type stability, Abstract and Applied Analysis, vol. 2012, article ID716936, 41 pages, doi:10.1155/2012/716936

[2] Cadariu, L. and Radu, V., Fixed point methods for the generalized stability of functional equations in a single variable, Fixed Point Theory A., vol. 2008, Article ID749392, 15 pages, doi:10.1155/2008/749392

[3] Hatori, O., Kobayasi, K., Miura, T., Takagi, H. and Takahasi, S. E., On the best constant of Hyers-Ulam stability, J. Nonlinear Convex Anal., 5 (2004), 387-393

[4] Hirasawa, G. and Miura, I., Hyers-Ulam stability of a closed operators in a Hilbert space, Bull. Korean Math. Soc., 43 (2006), 107-117

[5] Hyers, D. H., Isac, G. and Rassias, Th. M., Stability of Functional Equations in Several Variables, Birkhäuser, Basel, 1998

[6] Hyers, D. H., On the stability of the linear functional equation, Proc. Nat. Acad. Sci. U.S.A., 27 (1941), 222-224

[7] Jung, S.-M., Hyers-Ulam-Rassias stability of Jensen's equations and its applications, Proc. Amer. Math. Soc., 126 (1998), 3137-3143

[8] Kominek, Z., On a local stability of the Jensen functional equation, Demonstratio Math., 22 (1989), 499-507

[9] Lee, Y. H. and Jun, K. W., A generalization of the Hyers-Ulam-Rassias stability of the Pexider equation, J. Math. Anal. Appl., 246 (2000), 627-638

[10] Petru, T. P., Petruşel, A. and Yao, J.-C., Ulam-Hyers stability for operatorial equations and inclusions via nonself operators, Taiwanese J. Math., 15 (2011), 2195-2212

[11] Pop, V., Stability of some functional equations defined by quasiarithmetic means, Carpathian J. Math., 28 (2012), 151-156

[12] Popa, D. and Raşa, I., On the best constant in Hyers-Ulam stability of some positive linear operators, J. Math. Anal. Appl., In press Corrected Proofs DOI:10.1016/j.jmaa.2013.10.039

[13] Popa, D. and Raşa, I., On the stability of some classical operators from approximation theory, Expo. Math., 31 (2013), No. 3 205-214

[14] Popa, D. and Raşa, I. The Fréchet functional equation with applications to the stability of certain operators, J. Approx. Theory, 164 (2012), 138-144

[15] Rus, I. A., Remarks on Ulam stability of the operatorial equations, Fixed Point Theory, 10 (2009), No. 2, 305-320

[16] Ulam, S. M., Problems in Modern Mathematics, Wiley, New York, 1960

DePARTMENT OF MATHEMATICS

TECHNICAL UNIVERSITY OF CLUJ-NAPOCA

Memorandumului 28, 400114 Cluj-NAPOCA, Romania

E-mail address: Popa.Dorian@math.utcluj.ro

Received: 14.11.2013; In revised form: 09.09.2014; Accepted: 20.10.2014

2010 Mathematics Subject Classification. 39B82.

Key words and phrases. Cauchy, Jensen, Quadratic equations, Hyers-Ulam stability, best constant.

Corresponding author: Dorian Popa; Popa.Dorian@math.utcluj.ro 